Laporan Penelitian

\title{
Polipektomi sederhana endoskopik rawat jalan dilanjutkan steroid intranasal sebelum Bedah Sinus Endoskopik Fungsional
}

\author{
Retno S. Wardani, Endang Mangunkusumo \\ Divisi Rinologi, Departemen Ilmu Penyakit Telinga Hidung Tenggorok \\ Fakultas Kedokteran Universitas Indonesia - RS Dr. Cipto Mangunkusumo \\ Jakarta
}

\begin{abstract}
ABSTRAK
Latar belakang: Indikasi Bedah Sinus Endoskopik Fungsional (BSEF) pada polip hidung adalah kegagalan respons adekuat setelah terapi medikamentosa maksimal. Tujuan: Mengetahui proporsi penderita polip hidung yang responsif terhadap protokol terapi medikamentosa maksimal dengan polipektomi sederhana endoskopik serta terapi steroid intranasal selama 6 minggu. Pasien yang tidak responsif, menjalani terapi BSEF dan ditindak-lanjuti selama 12 bulan. Juga dievaluasi perbedaan profil ekspresi gen yang mempengaruhi perbedaan respons klinis tersebut. Metode: Desain penelitian adalah eksperimental dengan kontrol sendiri pra dan pasca intervensi polipektomi sederhana endoskopik dan terapi steroid intranasal selama 6 minggu pada penderita polip hidung bilateral. Pemeriksaan microarray yang divalidasi dengan pemeriksaan real time $R T-P C R$, dilakukan untuk mengetahui perbedaan profil ekspresi gen sebelum dan sesudah protokol terapi. Hasil: Sesudah protokol pengobatan terdapat 16 subjek $(55,17 \%)$ menunjukkan respons terapi baik, dan 13 subjek (44,83\%) dengan tanda klinis menetap atau memburuk, dan selanjutnya menjalani terapi BSEF. Tindak-lanjut selama 1 tahun pasca BSEF pada 13 subjek, didapatkan polip rekurens pada 5 subjek (17,24\%) dan tidak ada polip 8 subjek (27,6\%). Ekspresi gen F5 adalah variabel yang bermakna dengan nilai $\operatorname{Exp} B=0,042$ dan $\mathrm{p}=0,04$. Nilai Nagelkerke $R$ square sebesar 49,9\% menunjukkan kekuatan gen F5 sebagai determinan respons kesembuhan. Kesimpulan: Penelitian klinik dengan melakukan tindakan polipektomi sederhana endoskopik dilanjutkan terapi steroid intranasal sebagai terapi lini pertama pada polip hidung sebelum intervensi BSEF, mendapatkan bukti pada tingkat molekuler untuk dapat lebih memahami terjadinya proses resolusi inflamasi kronik.
\end{abstract}

Kata kunci: polip hidung, polipektomi sederhana endoskopik, bedah sinus endoskopik fungsional, gen F5,

\section{ABSTRACT}

Background: Functional Endoscopic Sinus Surgery (FESS) is only indicated for nasal polyps (NP) cases which not responsive to maximal medical treatment. Objectives: To find proportion of NPs responsive to maximal medical treatment protocol consisted of office based endoscopic simple polypectomy followed by a 6-week intranasal steroid. Subjects who failed the treatment protocol underwent FESS and followed up until 12 months. The difference of gene expression profile was also evaluated based on their different clinical responses. Method: An experimental study of pre and post self-control to evaluate patients with naïve bilateral nasal polyps who had underwent endoscopic simple polypectomy under local anesthesia followed by intranasal steroid for six weeks. Microarray examination validated by real time RT-PCR was performed to determine the difference of gene expression profile before and after protocol treatment. Result: There were 16 responsive subjects (55.17\%) to protocol treatment and 13 unresponsive subjects (44.83\%) that subsequently underwent FESS. Twelve months follow up showed recurrent nasal polyps in 5 subjects (17.24\%) and no recurrence in 8 subjects (27.6\%). F5 gene expression was the determinant 
in response to protocol treatment, with $\operatorname{Exp} B=0.042$ and $p=0.04$. Nagelkerke $R$ square value of $49.9 \%$ showed the equation of F5 as determinant of reponsiveness. Conclusion: Clinical research of endoscopic simple polypectomy followed by intranasal steroid before FESS intervention in bilateral NP obtained evidence in biomolecular level to gain deeper understanding of how resolution of chronic inflammation happened.

Keywords: nasal polyps, endoscopic simple polypectomy, functional endoscopic sinus surgery, F5 gene

Alamat korespondensi: Retno S. Wardani, Divisi Rinologi - Departemen THT FKUI - RSCM, Jl. Diponegoro 71 Jakarta, email: retno.wardani@ui.ac.id

\section{PENDAHULUAN}

Bedah Sinus Endoskopik Fungsional (BSEF) merupakan terapi bedah di bidang Rinologi untuk mengatasi kasus inflamasi hidung dan sinus paranasal, seperti rinosinusitis kronis dengan dan tanpa polip hidung, yang tidak sembuh dengan terapi maksimal medikamentosa, serta sebagai pendekatan untuk pengangkatan tumor jinak dan ganas. ${ }^{1}$

Falsafah dan konsep BSEF adalah mengembalikan fungsi dan atau mempertahankan semaksimal mungkin fungsi ventilasi dan drainase hidung dan sinus paranasal serta mempertahankan mukosa yang normal sebanyak mungkin agar terjadi proses penyembuhan dengan regenerasi epitel bertingkat semu bersilia dan sistem transport mukosilier. Dengan menggunakan endoskop melalui koridor hidung dan sinus paranasal, dapat diperoleh akses ke orbita, dasar tengkorak, fosa anterior dan fosa infratemporal. Keuntungan yang dapat diperoleh ialah tidak adanya luka parut di wajah, lama perawatan di rumah sakit yang lebih singkat dan visualisasi maksimal. Di sisi lain, komplikasi seperti hematoma atau perdarahan intraorbita akibat terpotongnya arteri etmoid anterior, trauma arteri karotis interna, cedera nervus optikus yang mengakibatkan kebutaan, cedera muskulus rektus medialis yang mengakibatkan strabismus, cedera dura yang mengakibatkan kebocoran cairan serebrospinal dapat terjadi jika pemahaman anatomi endoskopik tiga dimensi dan anatomi radiologik dinding lateral hidung dan daerah rawan tembus tidak dikuasai dengan baik.
Sesuai dengan indikasi, falsafah dan konsep BSEF maka penatalaksanaan polip hidung bilateral selalu didahului oleh terapi medikamentosa dengan tujuan mengurangi edem, mengecilkan ukuran polip serta mengurangi perdarahan durante operasi dan kemungkinan terjadinya komplikasi operasi BSEF akibat tidak adekuatnya visualisasi akibat perdarahan atau hilangnya penanda anatomi.

Panduan penatalaksanaan polip hidung yang dibuat oleh Kelompok Studi Rinologi PP PERHATI-KL pada tahun $2007,{ }^{2}$ menganjurkan untuk melakukan reduksi volume pada polip stadium 2 dan 3, memberikan terapi steroid oral dosis tinggi dengan penurunan bertahap dalam waktu 9 hari, serta steroid intranasal selama 4-12 minggu. Panduan ini merupakan modifikasi dari panduan penatalaksanaan dari EP3OS (European Position Paper on Rhinosinusitis and Nasal Polyps) yang hanya memberikan terapi steroid oral dan steroid intranasal sesuai dengan derajat polip dan keluhan pasien berdasarkan VAS (visual analogue scale). ${ }^{3}$ Reduksi volume polip dengan polipektomi sederhana endoskopik dianjurkan karena rerata penderita polip hidung yang mencari pengobatan di Indonesia datang dengan polip yang berukuran besar yaitu derajat 2 atau 3 . Selain memperkecil ukuran polip, keuntungan tambahan adalah memperluas area kontak mukosa hidung dan meningkatkan absorpsi steroid intranasal. Penggunaan steroid intranasal ditujukan untuk menghindari terjadinya efek samping steroid oral seperti diabetes melitus, hipertensi, iritasi lambung, moon face, osteoporosis dan lain-lain. 
Penelitian ini bertujuan untuk mendapatkan proporsi pasien polip hidung bilateral yang memberikan respons keberhasilan dengan protokol pengobatan polipektomi sederhana endoskopik dan pemberian steroid intranasal selama 6 minggu. Baik kelompok non-responder yang menjalani terapi bedah BSEF dan kelompok responder akan dievaluasi terhadap rekurensi polip 12 bulan pasca pengobatan protokol. Evaluasi keberhasilan terhadap respons protokol pengobatan dan tidak terjadinya rekurensi dilakukan dengan menilai perbedaan tingkat ekspresi gen sebelum dan sesudah protokol pengobatan. Ekspresi gen yang berperan pada proses kesembuhan diperiksa dengan microarray dan divalidasi dengan pemeriksaan real-time RT-PCR.

\section{METODE}

Tiga puluh satu penderita polip hidung bilateral yang datang ke Poliklinik Rawat Jalan Rinologi-Departemen THT FKUI RSCM diikutsertakan secara konsekutif pada periode waktu September 2009-Januari 2010, dan ditindak lanjuti sampai dengan Maret 2011.

Polipektomi sederhana endoskopik dilakukan dalam anestesi lokal dengan menyisipkan tampon kapas yang ditetesi larutan adrenalin:lidokain = 1/5000 ( 1 cc adrenalin 1/1000 diencerkan dengan $4 \mathrm{cc}$ lidokain) dan diolesi pada 2 sisi permukaan kapas dengan gel Xylocaine ${ }^{\mathrm{R}}$. Tampon disisipkan di antara massa polip dengan bantuan respatorium ke meatus medius, di superior perlekatan konka media di dinding lateral hidung, resesus sfenoetmoid, meatus inferior dan menutup seluruh permukaan polip hidung, dengan waktu antara 15-30 menit. Gel Xylocaine ${ }^{R}$ berguna sebagai preparat anestesi lokal yang sangat poten untuk menghilangkan edema melalui penghambatan serabut saraf sensorik tanpa myelin-tipe-c cabang nervus trigeminus; sehingga tangkai dan asal polip akan mudah diidentifikasi. Tindakan ini merupakan modifikasi dari penelitian yang dilakukan oleh Kanai. ${ }^{4}$

Setelah tampon dikeluarkan, dilakukann polipektomi sederhana endoskopik: tangkai polip atau polip yang melekat pada struktur anatomi KOM dipotong dengan gunting atau forsep potong lurus. Jumlah perdarahan minimal dan dibersihkan dengan alat penghisap. Pasca tindakan rongga hidung ditampon sementara dan setelah tampon dikeluarkan, evaluasi perdarahan dilakukan selama 30 menit sampai dengan 1 jam. Selanjutnya penderita dipulangkan dan tidak diperlukan rawat inap. Antibiotika amoksisilinasam klavulanat $500 \mathrm{mg} / 125 \mathrm{mg}$ diberikan 3 kali sehari selama 7 hari dan bila perlu dapat diperpanjang sampai dengan 14 hari. Steroid intranasal yang diberikan adalah mometason furoat dengan dosis $400 \mathrm{ug}$ per hari (2 semprot setiap rongga hidung, 2 kali sehari). Setiap 1 semprot mometason furoat memiliki dosis terukur $50 \mathrm{ug}$.

Kunjungan untuk kontrol dilakukan pada minggu pertama, minggu ke-2, minggu ke-4 dan minggu ke-6. Pada setiap kunjungan dilakukan nasoendoskopi dan penimbangan berat botol steroid intranasal untuk menilai kepatuhan subjek. Evaluasi ukuran polip hidung dilakukan pada minggu ke-6. Jika masih terdapat polip, dilakukan polipektomi sederhana endoskopik pada sisa polip, jika polip sudah menghilang, biopsi dilakukan pada prosesus unsinatus dan konka media.

BSEF dilakukan pada 13 subjek yang tidak respons dengan protokol terapi dan perawatan pasca operasi dilakukan sesuai dengan panduan baku perawatan pasca operasi.

Jaringan polip hidung yang berpasangan, sebelum dan sesudah protokol terapi dibagi menjadi 3 bagian untuk ekstraksi RNA, fiksasi dalam larutan formalin dan dibuat blok parafin serta penyimpanan sebagai jaringan segar yang direndam dalam tissue freezing medium dalam lemari es $-80^{\circ}$. Ekstraksi RNA, analisis microarray sampel RNA dan pemeriksaaan real time RT-PCR dilakukan di Research Laboratory of ENT Department Yong Lo Lin School of Medicine - National University Singapore.

Ekstraksi RNA total dari jaringan polip dalam RNAlater menggunakan Trizol (Invitrogen) 
dilanjutkan dengan pencucian Rneasy Mini Kit dengan tambahan perlakuan Dnase sesuai dengan pabrik pembuat (Qiagen).

Sampel RNA diperiksa integritasnya dengan mendeteksi pita 18s:28s pada gel elektroforesis. Jaringan polip pada sampel berpasangan dengan respons klinik terbaik $(\mathrm{n}=5)$ dilakukan pemeriksaan microarray. RNA dipreparasi untuk analisis microarray menggunakan protokol baku Affymetrix (Affymetrix, Inc.). 1ug total RNA ditranskripsi terbalik menjadi cDNA dua rantai. Selanjutnya transkripsi in-vitro dari cDNA dua rantai menjadi cRNA dilakukan menggunakan T7 polimerase dan biotinilated UTP. Biotinilated cRNA (15ug) difragmentasi dan dihibridisasi pada human U133 Plus 2.0 array. cRNA hibridisasi dideteksi dengan menggunakan streptavidin yang diperkuat dengan fikoeritrin dan divisualisasikan menggunakan pemindai laser. Data gambar (dokumem CEL) dikuantifikasi untuk memunculkan nilai ekspresi gen dan rasio ekspresi gen di antara sampel hibridisasi (heat map analysis). Untuk itu, dokumen CEL diimport ke dalam perangkat lunak GeneSpring 7.3 (Agilent Technologies) dan ditransformasi dengan Robust Multichip Analysis (RMA). Perangkat lunak tersebut selanjutnya digunakan untuk mengidentifikasi transkrip yang mengalami peningkatan/ penurunan ekspresi secara bermakna antara polip hidung sebelum dan sesudah terapi.

\section{HASIL}

Dari 31 penderita polip hidung bilateral, 2 dikeluarkan karena tidak dapat dilakukan polipektomi sederhana endoskopik yang ke-2 sehingga hanya ada 29 subjek yang mengikuti seluruh protokol penelitian. Respons terapi sesudah protokol pengobatan terdapat 16 subyek $(55,17 \%)$ menunjukkan respons terapi baik, dan 13 subjek $(44,83 \%)$ dengan tanda klinis menetap atau memburuk, dan selanjutnya menjalani terapi BSEF. Tindak lanjut selama 1 tahun pasca BSEF pada 13 subjek non-responder, didapatkan polip rekurens pada 5 subjek $(17,24 \%)$ dan polip tidak rekurens - tetap menghilang pada 8 subjek

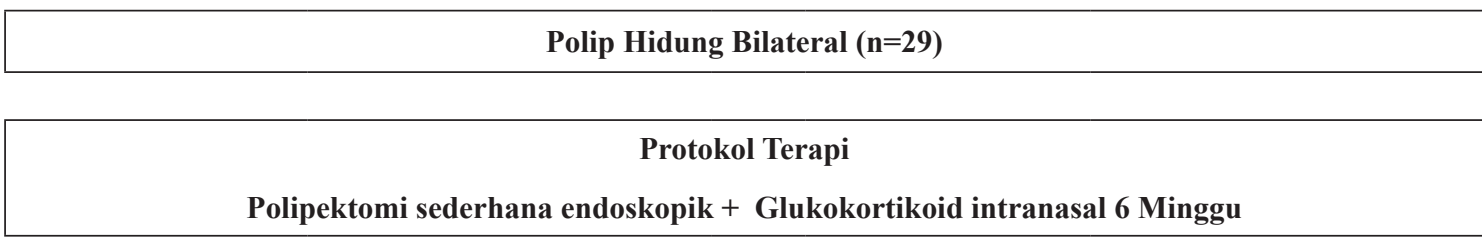

\begin{tabular}{|c|c|}
\hline $\begin{array}{c}\text { Tidak Respons Terhadap Protokol Terapi (n=13) } \\
\text { P2, P3, P4, P5, P7, P8, }\end{array}$ & $\begin{array}{c}\text { Respons Terhadap Protokol Terapi } \\
(\mathbf{n}=\mathbf{1 6})\end{array}$ \\
P12, P17, P22, P23, P25, P26, P27 & $\begin{array}{c}\text { P1, P6, P9, P10, P11, P13, P16, P18, P19, P20, } \\
\text { P21, P24, P28, P29, P30, P31 }\end{array}$ \\
\hline
\end{tabular}

\begin{tabular}{|c|c|c|c|}
\hline \multicolumn{4}{|c|}{ Tindak Lanjut 12 bulan } \\
\hline $\begin{array}{l}\text { Polip Rekuren } \\
\qquad(\mathrm{n}=5)\end{array}$ & $\begin{array}{c}\text { Sembuh } \\
\text { (Polip Tidak Rekuren) } \\
(\mathrm{n}=8)\end{array}$ & $\begin{array}{l}\text { Polip Rekuren } \\
\qquad(\mathrm{n}=6)\end{array}$ & $\begin{array}{c}\text { Sembuh } \\
\text { (Polip Tidak Rekuren) } \\
(\mathrm{n}=10)\end{array}$ \\
\hline P2, P3, P5, P12, P17 & $\begin{array}{c}\mathrm{P} 4, \mathrm{P} 7, \mathrm{P} 8, \mathrm{P} 22, \mathrm{P} 23, \mathrm{P} 25, \\
\mathrm{P} 26, \mathrm{P} 27\end{array}$ & $\begin{array}{c}\mathrm{P} 9, \mathrm{P} 11, \mathrm{P} 16, \mathrm{P} 18, \\
\mathrm{P} 24, \mathrm{P} 29\end{array}$ & $\begin{array}{c}\text { P1, P6, P10, P13, P19, P20, } \\
\text { P21, P28, P30, P31 }\end{array}$ \\
\hline
\end{tabular}

Gambar 1. Bagan tahapan penelitian untuk evaluasi respons terapi terhadap protokol pengobatan 6 minggu \& tindak lanjut 12 bulan 
$(27,6 \%)$. Pada kelompok responder, setelah evaluasi 12 bulan, subjek dengan polip rekurens sebanyak 6 orang $(20,9 \%)$ dan tetap menghilang sebanyak 10 orang $(30,48 \%)$. (Gambar 1)

Analisis microarray dilakukan pada lima pasang spesimen dari 5 subjek yang menunjukkan kriteria respons terbaik terhadap protokol pengobatan. Hasil pemeriksaan microarray menunjukkan 44 gen yang mengalami peningkatan regulasi dengan foldchange di atas 2, dan 18 gen yang menurun ekspresinya dengan foldchange di bawah. Seleksi kandidat gen diperoleh melalui heat map analysis dan hierarchical cluster, yaitu: 1) memiliki ekspresi gen dengan nilai ekspresi (foldchange) tertinggi, 2) menunjukkan nilai statistik yang stabil, yaitu dengan FDR (False Discovery Rate) kurang dari 10,3) belum pernah dilaporkan perannya pada penelitian polip hidung berdasarkan literatur yang ada sampai dengan tahun 2010. Didapati 6 gen yang akan divalidasi dengan real time RT PCR yaitu statherin (STATH), prolactin-induced protein (PIP), deleted in malignant brain tumor-1 (DMBT-1), haptoglobin (HP), lactotransferin (LTF), coagulation factor 5 (F5). (Gambar 2 dan Tabel 1)

Validasi ekspresi gen dengan real time RTPCR hanya dapat dilakukan pada 22 sampel berpasangan dari 22 subjek. Validasi ekspresi gen terpilih dibandingkan dengan gen pembanding (house keeping gene) yaitu GAPDH. Nilai median tingkatan ekspresi gen lalu dikelompokkan berdasarkan kelompok responder dan nonresponder terhadap protokol pengobatan 6 minggu dan kelompok polip rekurens dan tidak rekurens pasca BSEF 12 bulan. (Tabel 2 dan Tabel 3). Pada analisis protokol pengobatan 6 minggu, hanya gen F5 pada kelompok non-responder yang memiliki nilai interval kepercayaan terhadap median tidak bermakna; sedangkan pada analisis tabulasi silang dengan melakukan kategorisasi ulang ekspresi gen menjadi ekspresi tinggi dan ekspresi rendah berdasarkan nilai mediannya pada seluruh subjek, didapati gen F5 sebagai variabel gen yang signifikan terhadap keberhasilan protokol terapi, dengan hasil perhitungan statistik OR: 7,88;

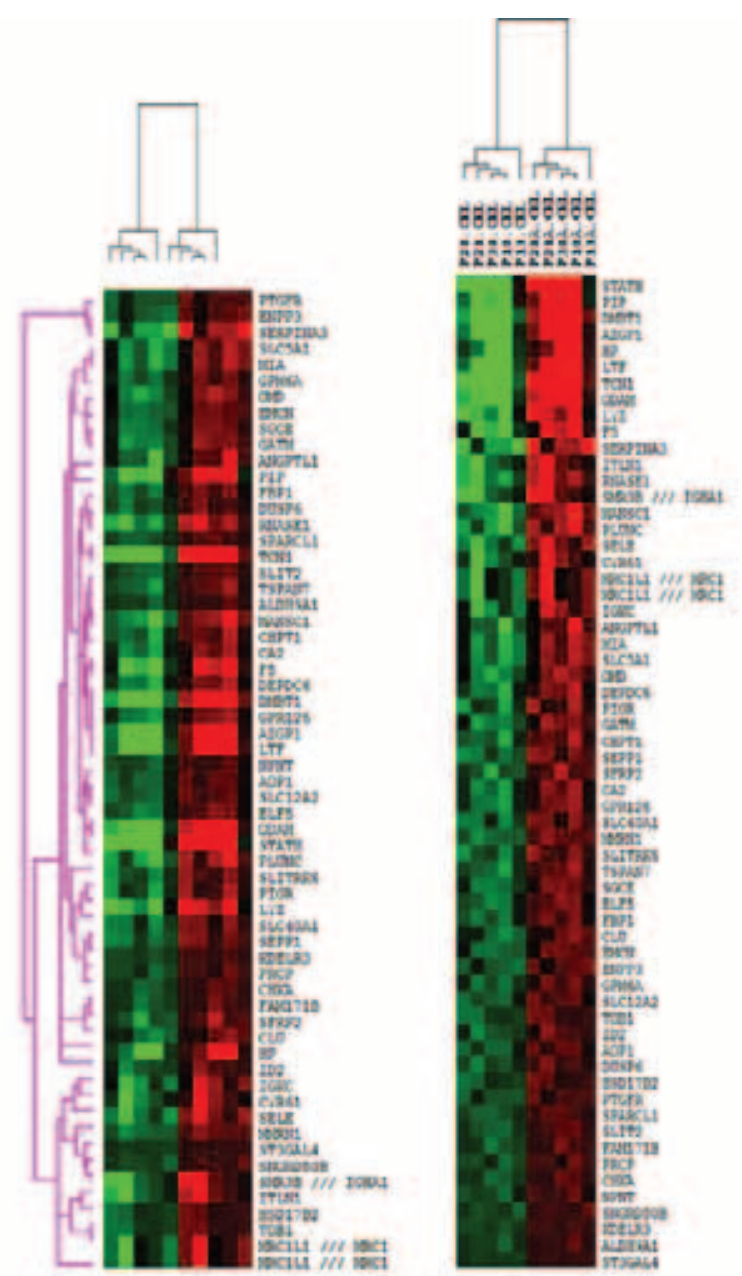

Gambar 2. Heat Map Analysis Microarray pada 5 pasang spesimen Kolom hijau: ekspresi gen subjek sebelum terapi (downregulated genes), kolom merah: ekspresi gen sesudah sesudah terapi (upregulated genes). Lajur menunjukkan jenis gen. Diagram pohon (dendogram)menghubungkan gen yang berkelompok(cluster) sesuai hirarki. 1a: Heat map analysis sebelum pengelompokkan (clustering) sesuai hirarki. 1b: Heat map analysis sesudah pengelompokkan (clustering) sesuai hirarki.

interval kepercayaan 95\%: 1,11-56,12. Dengan demikian ekspresi gen F5 yang lebih tinggi dari mediannya memiliki risiko sebesar 7,88 kali lebih besar untuk menyebabkan keberhasilan protokol terapi 6 minggu dibanding gen F5 yang ekspresinya rendah. Analisis multivariat dengan menggunakan regresi logistik dengan metode Forward Stepwise (Likelihood Ratio) menunjukkan bahwa gen F5 menunjukkan nilai $\operatorname{Exp}(\mathrm{B})=0,042, \mathrm{p}=0,04$ (IK 95\% 0,002-0,88), $R$ square (Nagelkerke) 49,9\%. 
Tabel 1. Ekspresi gen berdasarkan analisis Heat Map - Microarray

\begin{tabular}{|c|c|c|c|c|}
\hline Transcript cluster id & Gene symbol & Gene title & Fold change & FDR (\%) \\
\hline 8095422 & STATH & statherin & 115,33 & 8,81 \\
\hline 8136839 & PIP & prolactin-induced protein & 26,45 & 12,20 \\
\hline 7931108 & DMBT1 & deleted in malignant brain tumors 1 & 21,10 & $\mathbf{0}$ \\
\hline 8141374 & AZGP1 & alpha-2-glycoprotein 1, zinc-binding & 13,12 & 0 \\
\hline 7997188 & HP & haptoglobin & 12,85 & 8,81 \\
\hline 8086607 & LTF & lactotransferrin & 10,15 & $\mathbf{0}$ \\
\hline 7948444 & TCN1 & $\begin{array}{l}\text { transcobalamin I (vitamin B12 binding } \\
\text { protein, R binder family) }\end{array}$ & 10,13 & 0 \\
\hline 8095456 & ODAM & odontogenic, ameloblast associated & 8,95 & 0 \\
\hline 7957023 & LYZ & lysozyme (renal amyloidosis) & 8,31 & 8,81 \\
\hline 7922174 & F5 & $\begin{array}{l}\text { coagulation factor } V \text { (proaccelerin, } \\
\text { labile factor) }\end{array}$ & 4,90 & 8,81 \\
\hline 7976496 & SERPINA3 & $\begin{array}{l}\text { serpin peptidase inhibitor, clade A } \\
\text { (alpha-1 antiproteinase, antitrypsin), } \\
\text { member } 3\end{array}$ & 4,54 & 0 \\
\hline 7921690 & ITLN1 & intelectin 1 (galactofuranose binding) & 4,39 & 8,81 \\
\hline 7977615 & RNASE1 & $\begin{array}{l}\text { ribonuclease, RNase A family, } 1 \\
\text { (pancreatic) }\end{array}$ & 3,96 & 0 \\
\hline 8095491 & $\begin{array}{l}\text { SMR3B } / / / \\
\text { IGHA1 }\end{array}$ & $\begin{array}{l}\text { submaxillary gland androgen regulated } \\
\text { protein } 3 \mathrm{~B} / / / \text { immunoglobulin heavy } \\
\text { constant alpha } 1\end{array}$ & 3,80 & 8,81 \\
\hline 7961365 & MANSC1 & MANSC domain containing 1 & 3,68 & 0 \\
\hline 8061883 & PLUNC & $\begin{array}{l}\text { palate, lung and nasal epithelium } \\
\text { associated }\end{array}$ & 3,65 & 3,40 \\
\hline 7922229 & SELE & selectin $\mathrm{E}$ & 3,42 & 3,40 \\
\hline 7902687 & CYR61 & cysteine-rich, angiogenic inducer, 61 & 3,31 & 9,61 \\
\hline 8136709 & LOC93432 & maltase-glucoamylase-like pseudogene & 3,19 & 9,61 \\
\hline 7926410 & $\begin{array}{l}\text { MRC1L1/// } \\
\text { MRC1 }\end{array}$ & $\begin{array}{l}\text { mannose receptor, } \mathrm{C} \text { type } 1 \text {-like } 1 / / / \\
\text { mannose receptor, } \mathrm{C} \text { type } 1\end{array}$ & 3,09 & 9,61 \\
\hline 7926451 & $\begin{array}{l}\text { MRC1L1 /// } \\
\text { MRC1 }\end{array}$ & $\begin{array}{l}\text { mannose receptor, } \mathrm{C} \text { type } 1 \text {-like } 1 / / / \\
\text { mannose receptor, } \mathrm{C} \text { type } 1\end{array}$ & 3,09 & 9,61 \\
\hline 8043436 & IGKC & immunoglobulin kappa constant & 2,94 & 9,61 \\
\hline 7922598 & ANGPTL1 & angiopoietin-like 1 & 2,89 & 9,61 \\
\hline 8028924 & MIA & melanoma inhibitory activity & 2,81 & 9,61 \\
\hline 8072587 & SLC5A1 & $\begin{array}{l}\text { solute carrier family } 5 \text { (sodium/glucose } \\
\text { cotransporter), member } 1\end{array}$ & 2,72 & 8,81 \\
\hline 8162388 & OMD & Osteomodulin & 2,60 & 12,20 \\
\hline 8148059 & DEPDC6 & DEP domain containing 6 & 2,55 & 9,61 \\
\hline 7923929 & PIGR & polymeric immunoglobulin receptor & 2,47 & 8,81 \\
\hline 7988414 & GATM & $\begin{array}{l}\text { glycine amidinotransferase } \\
\text { (L-arginine:glycine amidinotransferase) }\end{array}$ & 2,44 & 9,61 \\
\hline 7958000 & CHPT1 & choline phosphotransferase 1 & 2,41 & 8,81 \\
\hline 8111915 & SEPP1 & selenoprotein $\mathrm{P}$, plasma, 1 & 2,41 & 8,81 \\
\hline 8103254 & SFRP2 & secreted frizzled-related protein 2 & 2,39 & 8,81 \\
\hline 8147132 & CA2 & carbonic anhydrase II & 2,38 & 9,61 \\
\hline 8122365 & GPR126 & G protein-coupled receptor 126 & 2,34 & 9,61 \\
\hline 8057677 & SLC40A1 & $\begin{array}{l}\text { solute carrier family } 40 \text { (iron-regulated } \\
\text { transporter), member } 1\end{array}$ & 2,32 & 8,81 \\
\hline
\end{tabular}




\begin{tabular}{|c|c|c|c|c|}
\hline Transcript cluster ID & Gene symbol & Gene title & Fold change & $F D R(\%)$ \\
\hline 7972239 & SLITRK6 & SLIT and NTRK-like family, member 6 & 2,30 & 8,81 \\
\hline 8166784 & TSPAN7 & tetraspanin 7 & 2,28 & 8,81 \\
\hline 8141035 & SGCE & sarcoglycan, epsilon & 2,17 & 9,61 \\
\hline 7947481 & ELF5 & $\begin{array}{l}\text { E74-like factor } 5 \text { (ets domain transcription } \\
\text { factor) }\end{array}$ & 2,14 & 9,61 \\
\hline 8162502 & FBP1 & fructose-1,6-bisphosphatase 1 & 2,08 & 9,61 \\
\hline 8149927 & CLU & Clusterin & 2,07 & 12,20 \\
\hline 8101957 & EMCN & Endomucin & 2,06 & 12,20 \\
\hline 8122071 & ENPP3 & $\begin{array}{l}\text { ectonucleotide pyrophosphatase/ } \\
\text { phosphodiesterase } 3\end{array}$ & 2,02 & 9,61 \\
\hline 8103789 & GPM6A & glycoprotein M6A & 1,97 & 9,61 \\
\hline 8107769 & SLC12A2 & $\begin{array}{l}\text { solute carrier family } 12 \text { (sodium/potassium/ } \\
\text { chloride transporters), member } 2\end{array}$ & 1,97 & 9,61 \\
\hline 8016739 & TOB1 & transducer of ERBB2, 1 & 1,96 & 9,61 \\
\hline 8040103 & ID2 & $\begin{array}{l}\text { inhibitor of DNA binding 2, dominant } \\
\text { negative helix-loop-helix protein }\end{array}$ & 1,94 & 12,20 \\
\hline 8132118 & AQP1/// INMT & $\begin{array}{l}\text { aquaporin } 1 \text { (Colton blood group) /// } \\
\text { indolethylamine N-methyltransferase }\end{array}$ & 1,92 & 9,61 \\
\hline 7965335 & $\begin{array}{l}\text { DUSP6 } / / / \\
\text { LOC100131490 }\end{array}$ & $\begin{array}{l}\text { dual specificity phosphatase } 6 / / / \\
\text { hypothetical LOC100131490 }\end{array}$ & 1,91 & 9,61 \\
\hline 7997491 & HSD17B2 & hydroxysteroid (17-beta) dehydrogenase 2 & 1,89 & 9,61 \\
\hline 7902527 & PTGFR & prostaglandin $\mathrm{F}$ receptor $(\mathrm{FP})$ & 1,87 & 9,61 \\
\hline 8101659 & SPARCL1 & SPARC-like 1 (hevin) & 1,86 & 9,61 \\
\hline 8094301 & SLIT2 & slit homolog 2 (Drosophila) & 1,86 & 9,61 \\
\hline 8046895 & FAM171B & $\begin{array}{l}\text { family with sequence similarity } 171 \text {, } \\
\text { member B }\end{array}$ & 1,85 & 9,61 \\
\hline 7950731 & PRCP & prolylcarboxypeptidase (angiotensinase C) & 1,84 & 9,61 \\
\hline 7949916 & CHKA & choline kinase alpha & 1,81 & 9,61 \\
\hline 8096704 & NPNT & Nephronectin & 1,78 & 9,61 \\
\hline 8127989 & SNORD50B & small nucleolar RNA, C/D box 50B & 1,78 & 9,61 \\
\hline 8073015 & KDELR3 & $\begin{array}{l}\text { KDEL (Lys-Asp-Glu-Leu) endoplasmic } \\
\text { reticulum protein retention receptor } 3\end{array}$ & 1,71 & 9,61 \\
\hline 7921970 & ALDH9A1 & $\begin{array}{l}\text { aldehyde dehydrogenase } 9 \text { family, member } \\
\text { A1 }\end{array}$ & 1,70 & 12,20 \\
\hline 7945110 & ST3GAL4 & $\begin{array}{l}\text { ST3 beta-galactoside alpha-2,3- } \\
\text { sialyltransferase } 4\end{array}$ & 1,59 & 12,20 \\
\hline
\end{tabular}

Fold change: perbedaan ekspresi sebelum dan sesudah terapi. FDR: false discovery rate. 
Tabel 2. Nilai median tingkatan ekspresi gen (Median fold change) polip hidung berdasarkan kelompok responder dan non-responder terhadap protokol terapi 6 minggu

\begin{tabular}{|c|c|c|c|c|}
\hline \multirow[b]{2}{*}{$\begin{array}{l}\text { Gene } \\
\text { title }\end{array}$} & \multicolumn{2}{|c|}{ Responder } & \multicolumn{2}{|c|}{ Non-Responder } \\
\hline & $\begin{array}{c}\text { Median } \\
\text { Fold } \\
\text { Change }\end{array}$ & $\begin{array}{c}95 \% \\
\text { Confidence } \\
\text { Interval }\end{array}$ & $\begin{array}{c}\text { Median } \\
\text { Fold } \\
\text { Change }\end{array}$ & $\begin{array}{c}95 \% \\
\text { Confidence } \\
\text { Interval }\end{array}$ \\
\hline STATH & 300,42 & $\begin{array}{l}1,34- \\
1257,32\end{array}$ & 72,76 & $\begin{array}{l}21,81- \\
1285,91\end{array}$ \\
\hline PIP & 19,56 & $\begin{array}{l}1,75- \\
130,70\end{array}$ & 15,71 & $3,84-29,79$ \\
\hline LTF & 18,49 & $\begin{array}{l}1,66- \\
151,22\end{array}$ & 2,78 & $\begin{array}{c}1,10- \\
323,667\end{array}$ \\
\hline DMBT1 & 17,50 & $\begin{array}{l}1,75- \\
127,98\end{array}$ & 18,80 & $\begin{array}{c}1,88- \\
2247,89\end{array}$ \\
\hline $\mathrm{HP}$ & 7,53 & $\begin{array}{l}1,58- \\
136,39\end{array}$ & 13,49 & $1,22-88,21$ \\
\hline F5 & 3,72 & $\begin{array}{l}1,37- \\
23,06\end{array}$ & 1,81 & $0,96-10,08$ \\
\hline
\end{tabular}

Tabel 3. Nilai median tingkatan ekspresi gen (Median fold change) polip hidung berdasarkan kelompok tidak rekuren dan rekuren pada periode tindak lanjut 12 bulan

\begin{tabular}{|c|c|c|c|c|}
\hline \multirow{2}{*}{$\begin{array}{l}\text { Gene } \\
\text { Title }\end{array}$} & \multicolumn{2}{|c|}{$\begin{array}{l}\text { Tidak Rekuren } \\
\text { (Sembuh) }\end{array}$} & \multicolumn{2}{|c|}{ Rekuren } \\
\hline & $\begin{array}{c}\text { Median } \\
\text { Fold } \\
\text { Change }\end{array}$ & $\begin{array}{c}95 \% \\
\text { Confidence } \\
\text { Interval }\end{array}$ & $\begin{array}{c}\text { Median } \\
\text { Fold } \\
\text { Change }\end{array}$ & $\begin{array}{c}95 \% \\
\text { Confidence } \\
\text { Interval }\end{array}$ \\
\hline STATH & 351,98 & $\begin{array}{l}21,81- \\
1257,32\end{array}$ & 6,22 & $\begin{array}{l}0,13- \\
1024,97\end{array}$ \\
\hline PIP & 19,56 & $\begin{array}{l}3,84- \\
41,70\end{array}$ & 8,54 & $0,39-29,79$ \\
\hline LTF & 10,63 & $\begin{array}{l}1,90- \\
44,23\end{array}$ & 16,02 & $1,01-630,72$ \\
\hline DMBT1 & 17,50 & $\begin{array}{c}4,61- \\
120,38\end{array}$ & 18,80 & $\begin{array}{l}0,99- \\
1179,18\end{array}$ \\
\hline HP & 19,99 & $\begin{array}{l}2,08- \\
94,86\end{array}$ & 7,53 & $0,84-13,50$ \\
\hline F5 & 2,14 & $\begin{array}{l}1,37- \\
7,33\end{array}$ & 2,67 & $0,96-39,77$ \\
\hline
\end{tabular}

Pada periode tindak lanjut 12 bulan, gen STATH, PIP, DMBT-1, LTF, HP, F5 menunjukkan ekspresi yang lebih tinggi secara bermakna pada kelompok polip tidak rekurens, dan pada kelompok rekurens gen LTF menunjukkan tingkatan ekspresi yang bermakna pada kelompok polip rekurens berdasarkan interval kepercayaan $95 \%$ terhadap nilai median.

\section{DISKUSI}

Pada penelitian ini dibuktikan bahwa 6 molekul seroprotein yang diekspresikan oleh gen dengan nama yang sama memiliki peran terhadap keberhasilan pengobatan serta mencegah terjadinya rekurensi polip hidung. Seroprotein nasal adalah protein yang ditemukan pada epitel hidung, dan dapat berasal dari kelenjar seromusinosa, sel goblet bahkan protein-protein yang merupakan transudat, material ekstravasasi dari pembuluh darah. STATH dan PIP adalah protein yang dihasilkan oleh kelenjar submukosa hidung dan jika dihubungkan dengan keberhasilan respon pengobatan adalah untuk mengembalikan homeostasis yang terkait dengan keseimbangan transpor ion dan air pada penderita polip hidung. ${ }^{5}$ Pada makalah ini akan dibahas lebih mendalam tentang peran gen F5 yang terkait dengan peran epitel hidung yang bukan hanya merupakan sawar epitel (epithelial barrier) yang bersifat fisikmekanik tetapi juga mencerminkan kemampuan epitel hidung untuk menjawab adanya perubahan lingkungan, invasi patogen, pajanan alergen dan juga trauma. Dilaporkan juga bahwa epitel hidung mampu memproduksi mediator yang memiliki fungsi imuno-modulator dan menjadi komponen aktif dari respons imunologi melalui proses rekruitmen dan aktivasi sel-sel sistem imunitas. ${ }^{6}$

Faktor koagulasi 5 (F5), yang dikenal juga sebagai pro accelererin, labile factor, berbeda dengan faktor koagulasi lain, protein ini tidak diaktivasi secara enzimatik tetapi berfungsi sebagai kofaktor. F5 bersirkulasi di dalam plasma sebagai molekul rantai tunggal dengan waktu paruh sekitar 12-36 jam. F5 mampu berikatan dengan platelet yang teraktivasi dan diaktivasi oleh thrombin. F5 aktif merupakan kofaktor kompleks trombinase Faktor Xa bersama dengan ion kalsium dan bekerja untuk mengkonversi protrombin menjadi thrombin pada membran sel permukaan. Selain fungsi untuk mendukung fungsi transudasi platelet dan serum pembuluh darah dalam proses koagulasi, aktivasi platelet dan penyembuhan luka, F5 juga berperan dalam komposisi seroprotein nasal untuk membantu 
sistem sawar epitel (epithelial barrier) secara tidak langsung melalui efektor PAR-2 (Protease Activated Receptor-2) yang akan mengaktivasi protease pada pajanan alergen Der P1, Pen C13, alergen kecoa, alergen aspergillus dan alternaria. ${ }^{3}$ Penelitian ini akan menjadi dasar bagi penelitian selanjutnya pada penderita rinitis alergi untuk membuktikan bahwa proses inflamasi alergik kronik bisa disebabkan defek pada transudasi F5 untuk mendukung kekuatan sawar epitel.

Resolusi inflamasi adalah suatu proses aktif yang terkontrol dan terkendali untuk mengakhiri inflamasi melalui penekanan ekspresi gen pro-inflamasi, penghentian migrasi dan aktivasi leukosit, dan pembersihan sel-sel proinflamasi melalui apoptosis dan fagositosis. Penelitian terkini menunjukkan bahwa resolusi inflamasi diperankan oleh mediator lipid, seperti lipoksin, resolvin, dan derivat prostaglandin (cyclopentenone prostaglandin-cyPGs) ${ }^{7,8}$ Levi et $\mathrm{al}^{9}$ menunjukkan suatu hubungan dua arah (bidirectional) antara inflamasi dan koagulasi, sedangkan Frangogiannis ${ }^{10}$ melaporkan regulasi respons inflamasi pada proses penyembuhan miokard. Faktor koagulasi atau protein antikoagulan dapat mengaktivasi reseptor sel spesifik pada sel-sel mononuklear atau sel endotel sehingga sehingga terjadi apoptosis sel-sel proinflamasi. Proses inflamasi kronik terjadi akibat terganggunya sinyal berhenti (stop signals) pada inflamasi akut karena gangguan sinyal atau tidak teraturnya sinyal untuk mengendalikan proses resolusi inflamasi. ${ }^{7,8}$

Pada penelitian ini didapatkan bahwa faktor determinan terhadap respons kesembuhan adalah F5, karena secara bermakna menyebabkan kesembuhan 7,88 kali lebih besar pada kelompok responder dibandingkan kelompok non-responder. Sampai saat ini proses kesembuhan polip hidung terkait dengan proses resolusi inflamasi kronik serta dihubungkan dengan faktor koagulasi, belum pernah dilaporkan dalam literatur tetapi didapatkan dalam penelitian ini.

Proses membuat luka baru untuk memicu suatu kesembuhan merupakan hal yang sering dilakukan di bidang THT seperti tindakan melukai tepi-tepi membran timpani yang perforasi agar terjadi regenerasi sel baru dan menutupnya perforasi dan mendapatkan membran timpani yang kembali utuh. Proses yang sama terjadi juga pada polipektomi sederhana endoskopik, karena trauma yang terjadi justru akan memicu respons penyembuhan dan resolusi inflamasi kronik melalui aktivasi platelet yaitu F5. Berdasarkan analisis multivariat, dengan nilai Exp $B=0,042$ dan $\mathrm{p}=0,04$ peningkatan gen $\mathrm{F} 5$ memberikan risiko kesembuhan lebih besar 0,042 kali dibanding dengan gen F5 yang tidak mengalami peningkatan ekspresi. Nilai Nagelkerke $R$ square sebesar 49,9\% menunjukkan permodelan ini mampu memperlihatkan kekuatan 1 variabel yaitu gen F5 sebagai determinan proses penyembuhan luka dan resolusi inflamasi kronik, tetapi selain gen F5 masih ada variabel-variabel lain yang belum dapat diidentifikasi dan mungkin mempengaruhi respons kesembuhan sebesar $100 \%-49,9 \%=41,1 \%$. Hal ini sesuai dengan konsep penulis bahwa proses inflamasi baik pro-inflamasi ataupun resolusi inflamasi, proses penyembuhan luka adalah seperti sebuah orkestra yang memainkan simfoni dengan harmonis. Dalam orkestra ada pemain dan instrumen musik yang dominan, tetapi instrumen musik yang hanya dimainkan sesekali juga sama pentingnya, karena tetap diperlukan untuk menjaga kelengkapan harmoni dan keindahan sebuah simfoni. Konsep peneliti ini didukung oleh Prof. Heinz Stammberger, MD, Hon. FRCS(Ed), FRCS (Eng), Hon. FACS, Professor, Head of Department of General ENT Head \& Neck Surgery Graz University, Graz Austria: “... your thoughts on nasal polyps are completely in my line but unfortunately these thoughts cannot be immediately translated into our medical action for our patients. The problem is that all researchers have been into extreme details to discover "the one and only" switch which is wrong in the immune system or homeostasis of this disease, be this Il5, Th17, MBP, fungal hyper-responsiveness, "allergy", Staph. aureus superantigens, alloproteinases etc, etc. This 
immune system however, is an extremely complex thing and rather can be looked at not as a single "organism", but rather as a colony of millions of ants, which act and function like one organisms. This however, needs - as you put it - homeostasis, which apparently can be interfered with in multiple ways. So by trying to analyse individual ants with the name of Il5, Staph aureus, allergy etc, etc., ...we will not come to conclusions."

Penelitian inflamasi di bidang biomolekuler tidak dapat dilepaskan dari peran klinisi, karena gambaran klinik yang lengkap akan mempermudah pemahaman interaksi biologik di tingkat molekul. Fokus pada penelitian ini adalah mengetahui respons polip hidung bilateral terhadap terapi, sehingga analisis di tingkat molekul secara sistematik juga dikaitkan dengan peran molekul pada proses penyembuhan luka (wound healing) yang ditandai dengan terjadinya resolusi inflamasi. Polip hidung yang mengalami rekurensi sesudah terapi medikamentosa dan intervensi BSEF, merupakan pekerjaan rumah untuk penelitian selanjutnya.

Bukti keberhasilan pengobatan polip hidung di tingkat klinik dan didukung bukti di tingkat molekuler, berdasarkan prinsip kedokteran berbasis bukti (evidence based medicine), memberikan bukti di tingkat IIB dengan rekomendasi B. Dengan demikian diharapkan dapat menyakinkan dokter spesialis THT bahwa penatalaksanaan lini pertama polip hidung bilateral, yang merupakan penyakit inflamasi, adalah terapi medikamentosa maksimal dan bukan BSEF. BSEF hanya diindikasikan untuk polip hidung bilateral yang tidak responsif terhadap terapi maksimal medikamentosa. Kompetensi untuk melakukan BSEF dengan koordinasi tangan, mata dan otak yang baik, juga akan diasah dengan banyak melakukan tindakan-tindakan di poliklinik, seperti melakukan polipektomi sederhana endoskopik. Tujuan akhirnya adalah keselamatan pasien agar terhindar dari 'bencana' akibat komplikasi BSEF.

\section{KEPUSTAKAAN}

1. Lund VJ, Stammberger H, Nicolai P, Castelnuovo. European Position Paper on Endoscopic Management of Tumours of the Nose, Paranasal Sinuses and Skull Base. Rhinol 2010; 22(Suppl):1-143

2. Soetjipto D, Wardani RS, et al. Panduan penatalaksanaan penyakit di bidang THT. PP PERHATI-KL, 2007

3. Fokkens WJ, Lund V, Mullol J. European Position Paper on Rhinosinusitis and Nasal Polyps.Rhinol Suppl,2007:1-139

4. Kanai A, Suzuki A, Kobayashi M, Hoka S. Intranasal lidocaine $8 \%$ spray for second-division trigeminal neuralgia. Br J Anaesth 2006; 97(4):559-63.

5. Wardani RS, Mangunkusumo E, Gangguan transport ion pada polip hidung, ORLI 2011; 41(2):78-85

6. Vroling AB, Duinsbergen D, Fokken WJ, van Drunnen $\mathrm{CM}$, Allergen induced gene expression of airway epithelial cells shows a possible role for TNF-a. Allergy 2007; 62(11):1310-9

7. Serhan CN. Resolution of inflammation: the devil in the flask and in the details. Faseb J 2011; 25:1441-8

8. Lawrence T, Willoughby DA, Gilroy DW. Antiinflammatory lipid mediators and insights into the resolution of inflammation. Nat Rev Immunol 2002; 2:787-95

9. Levi M, van der Poll, Buller HR. Bidirectional relation between inflammation and coagulations. Circulation 2004; 109:2698-704

10. Frangogiannis N. Regulation of the inflammatory response in cardiac repair. Circ Res 2012; 110:159-73.

11. Personal email correspondence to Professor Heinz R. Stammberger, 2011. 